\title{
LIPID PROFILES OF MEDITERRANEAN MORAY, MURAENA HELENA, EUROPEAN CONGER, CONGER CONGER, AND EUROPEAN EEL, ANGUILLA ANGUILLA (ACTINOPTERYGII: ANGUILLIFORMES)
}

\author{
Domagoj ĐIKIĆ ${ }^{* 1}$, Irena LANDEKA ${ }^{2}$, Radovan FUCHS $^{3}$, Daria SKARAMUCA ${ }^{1}$, \\ Sanja MATIĆ-SKOKO ${ }^{4}$, Pero TUTMAN ${ }^{4}$, Zdenko FRANIĆ ${ }^{3}$, Ivona CVETKOVIĆ ${ }^{1}$, \\ and Boško SKARAMUCA ${ }^{5}$ \\ ${ }^{1}$ Department of Animal Physiology, Faculty of Science, University of Zagreb, Croatia \\ ${ }^{2}$ Faculty of Food Technology and Biotechnology, University of Zagreb, Croatia \\ ${ }^{3}$ Institute of Medical Research, University of Zagreb, Croatia \\ ${ }^{4}$ Institute of Oceanographic Research, Split, Croatia \\ ${ }^{5}$ University of Dubrovnik, Dubrovnik, Croatia
}

ĐikićD., LandekaI., Fuchs R., SkaramucaD., Matić-SkokoS., TutmanP., FranićZ., Cvetković I., Skaramuca B. 2017. Lipid profiles of Mediterranean moray, Muraena helena, European conger, Conger conger, and European eel, Anguilla anguilla (Actinopterygii: Anguilliformes). Acta Ichthyol. Piscat. 47 (1): 1-11.

Background. The current topics in fish fatty acid (FA) research include qualitative comparisons, trophic transfer as nutritive sources of FA, evolutionary comparison of synthesis pathways, and potential application of most efficient fish desaturases and elongases. FA are scarcely investigated in Elopomorpha and Anguilliformes, except for common- and Japanese eels. In this study determines the differences in lipid composition of FA between species of the order Anguilliformes, representing three families, Mediterranean moray, Muraena helena Linnaeus, 1758; European conger, Conger conger (Linnaeus, 1758); and European eel Anguilla anguilla (Linnaeus, 1758) (thereafter moray, conger, and eel, respectively). These are the first results on FA for the moray.

Material and methods. The fishes were collected in September 2011 on the Croatian coast of the Adriatic Sea, including the Neretva River estuary. Total lipids were extracted and the fatty acid profile in total lipid isolates were determined by gas chromatography of the corresponding methyl esters, obtained by acid methanolysis. A Hewlett Packard HP 5890A capillary gas chromatograph equipped with flame ionization detector (FID) was used.

Results. Both moray and conger were less fatty than eel but had higher $\omega$ FA content, especially $\omega-3$. Moray and conger, contained more proteins than lipids, while in eel, lipids exceeded the crude protein content. Conger was the leanest fish among the three. The qualitative SFA, MUFA, and PUFA were species specific (myristic FA characteristic for moray). PUFA were higher in moray and conger, due primarily to DHA. Moray showed the most favourable qualitative lipid content and profile and best ratio of $\omega-3$ to $\omega-6$ FA. Moray had 7.6- and conger 11-fold more DHA than eel. Approximate ratios along $\omega$-3 biosynthesis pathway, show that there was 6-fold more EPA than $\alpha$-LNA in moray and conger, and only 1.64- in eel, 5.63-fold, and 11.27-fold more DHA than DPA in Mediterranean moray and conger, respectively, and only 1.03-fold more in eel Approximate ratios along $\omega-3$ biosynthesis pathway, show that there was 6 -fold more EPA than $\alpha$-LNA in moray and conger, and only 1.64fold in eel. DHA was 5.63-fold, and 11.27-fold more abundant than DPA in moray and conger, respectively. In comparison, eel had only 1.03-fold more DHA than DPA.

Conclusions. Although trophic status and environment are the most determined, the differences in individual FA ratios might indirectly suggest different physiological utilization of elongation pathways in each species. Presently reported results draw focus on Muraena helena and Conger conger to be included in the studies elongase and desaturase pathways in teleost fish.

Keywords: fatty acids, elongase, desaturase, Muraenidae, Congridae, Anguillidae

\footnotetext{
* Correspondence: Prof. Dr. Domagoj Đikić, Zavod za animalnu fiziologiju, Biološki odsjek, Prirodoslovno matematički fakultet, Sveučilište u Zagrebu, Rooseveltov trg 6, 10000 Zagreb, Croatia, phone: +00 385915898 159, e-mail: (DĐ) magistar_djikic1@yahoo.com,domagoj.djikic@biol.pmf.hr, (IL) ilandeka@pbf.hr, (RF)dr.radovanfuchs@gmail.com, (DS)daria.skaramuca@zg.t-com.hr, (SMS)sanja@izor.hr, (PT) tutman@izor.hr, (ZF) franic@imi.hr, (IC)nonacvetkovic@gmail.com, (BS)bosko.skaramuca@unidu.hr.
} 


\section{INTRODUCTION}

Lipids, along with proteins are main constituents of fish organism (Tocher 2003). The fatty acid (FA) profiles are important for fish comparative biochemistry and for understanding the regulatory mechanisms of fish physiology (Li et al. 2015, Murray et al. 2015, Liang et al. 2016). Fishes constitute a major link in the trophic transfer of FA from lower marine organisms (e.g., plankton). They are also a crucial source of FA in nutrition (Tillander et al. 2014). The importance of fish FA research is enhanced by the role of the essential fatty acids and their physiological implications where optimal ratios of $\omega-3 \div \omega-6$ FA in the diet and their beneficial effects on health have been the subject of on-going discussion (Shahidi and Finley 2001, Ekanayake et al. 2005, Lombardi et al. 2006, Teparić et al. 2012, Mu and Müllertz 2015, Weylandt et al. 2015).

Comparative inter- and intra-species studies have shown that several taxonomic groups and species of fish are recognized by their ability to synthesize (Kabeya et al. 2015), biochemically convert, or store essential FA (Tocher 2003, Monroig et al. 2011, Xue et al. 2014, Castro et al. 2016, Geay et al. 2016). The most frequently studied fish higher taxa, rich in lipids and $\omega$ FA, are the Salmoniformes, such as Atlantic salmon, Salmo salar Linnaeus, 1758 (see Betancor et al. 2016); Gadidae, such as Atlantic cod, Gadus morhua Linnaeus, 1758 (see Li et al. 2015), and Anguilliformes, such as European eel, Anguilla anguilla (Linnaeus, 1758). The FA profiles of economically important (and farmed) eel species such as, A. anguilla; Anguilla japonica Temminck et Schlegel, 1846; Anguilla australis Richardson, 1841, have been widely studied, in their growth phases (Haro and Castro-Santos 2000, van Ginneken et al. 2007, Ghazali et al. 2013), gonad maturation and spawning (Mazzeo et al. 2010, Baeza et al. 2015a, 2015b, Butts et al. 2015, Dębowska et al. 2015), thermal adaptation (Baeza et al. 2014), energy storage (Boerrigter et al. 2015), immunology (Shahkar et al. 2016), and even coevolution of FA compositions between eels and their parasites (Aitzetmüller et al. 1994). However, records on FA profiles and physiology of other anguilliform species, especially the natural populations, are scarce or lacking. For some species, such as the European conger, Conger conger (Linnaeus, 1758), there are single papers on FA composition (Varljen et al. 2003) and antioxidant and immunomodulatory properties of conger oil (Ekanayake et al. 2005, Lombardi et al. 2006) with general representations of major FA groups only. On the other hand, for the majority of anguilliform species, such as the Mediterranean moray, Muraena helena Linnaeus, 1758, a representative of the Muraenidae, there are no published data on FA. The Mediterranean moray has been a common, nutritionally important species since antiquity, and the muraenid fishes are well represented globally in world oceans, thus lack of such data is surprising.

Previously, we studied the differences in comparative physiology, growth biology (Matić-Skoko et al. 2011, 2012), immune system, and blood cells (Đikić et al. 2013) of Mediterranean moray and European conger. These and other studies revealed prominent differences in the pray composition of both species which are top-order predators of high trophic status. Within these reports, by reporting the extensive species list, it was shown that Mediterranean moray consumed by 6.84 percentage points (pp) less crustaceans (weight/weight) and by $9.23 \mathrm{pp}$ more fish (weight/weight) within their prey than European conger (Matić-Skoko et al. 2012, 2014, Anastasopoulou et al. 2013, Sallami et al. 2014, 2015). Because it is known from experimental manipulation of various FA in the diet of eels in captivity and in aquaculture that there are links between dietary intake and the incorporation of FA (Støttrup et al. 2013) we formulated a hypothesis that the composition of total lipids and FA in Mediterranean moray and European conger might show differences mainly because of presented feeding differences. Besides, in a previous study of POP bioaccumulation in Mediterranean moray (Đikić et al. 2013) we were curious whether Mediterranean moray has a high enough total lipid content and lipophilic potential for bioaccumulation studies, however we could not find any published data on total lipid levels in this fish.

Thus the aim of this study was to compare the differences in the total lipid content and their fatty acid (FA) compositions between three angiulliform species, Mediterranean moray, European conger, and European eel (thereafter moray, conger, and eel, respectively).

\section{MATERIALS AND METHODS}

The specimens of moray, conger, and eel, were collected on the Croatian coast of the Adriatic Sea, including the Neretva River estuary. The following parameters of the fish tissues were determined: dry matter, moisture, ash, total lipids, crude proteins, and individual fatty acid content within the isolated total lipids. The sampled wild eels were used as an out-group (in regard to its different environment) and internal standard control of accuracy of the biochemical methods (i.e., biological control). For wild caught eels and for some farmed eels data on FA are at least partially available in literature which also makes this species also comparable.

Material. Moray and conger specimens were collected during the same field trip, in September 2011, and on the same location in the Adriatic Sea $\left(42.761019^{\circ} \mathrm{N}, 17.765090^{\circ} \mathrm{W}\right.$, Fig. 1), Elaphiti Islands near Dubrovnik, Croatia. Eel were collected in the delta and estuary of the Neretva River entering the Adriatic Sea $\left(43.033655^{\circ} \mathrm{N}, 17.551200^{\circ} \mathrm{W}\right.$, Fig. 1) two days later. To assure approximate uniformity of the samples the fish collected were comparable in age. The fish basic parameters were as follows, moray (age $=7.0 \pm 2.12$ years, total length $72.37 \pm 13.4 \mathrm{~cm}$ ), conger (age $=5.6 \pm$ 1.00 years, total length $70.00 \pm 8.6 \mathrm{~cm})$, eel $(\mathrm{age}=7.00$ \pm 1.67 years, total length $57.35 \pm 8.77 \mathrm{~cm}$ ). Full details are provided by Matić-Skoko et al. $(2011,2012)$ and Đikić et al. (2013). Fishes ( $n=30 ; 10$ per species) were anesthetized (MS-222) and sacrificed by decapitation prior to sample preparation. The procedures performed were in accordance with the EU Directive 63/2010 (Anonymous 2010) and its subsequent amendments and in accordance with the Croatian national regulation concerning experiments on animals (Anonymous 2006). 


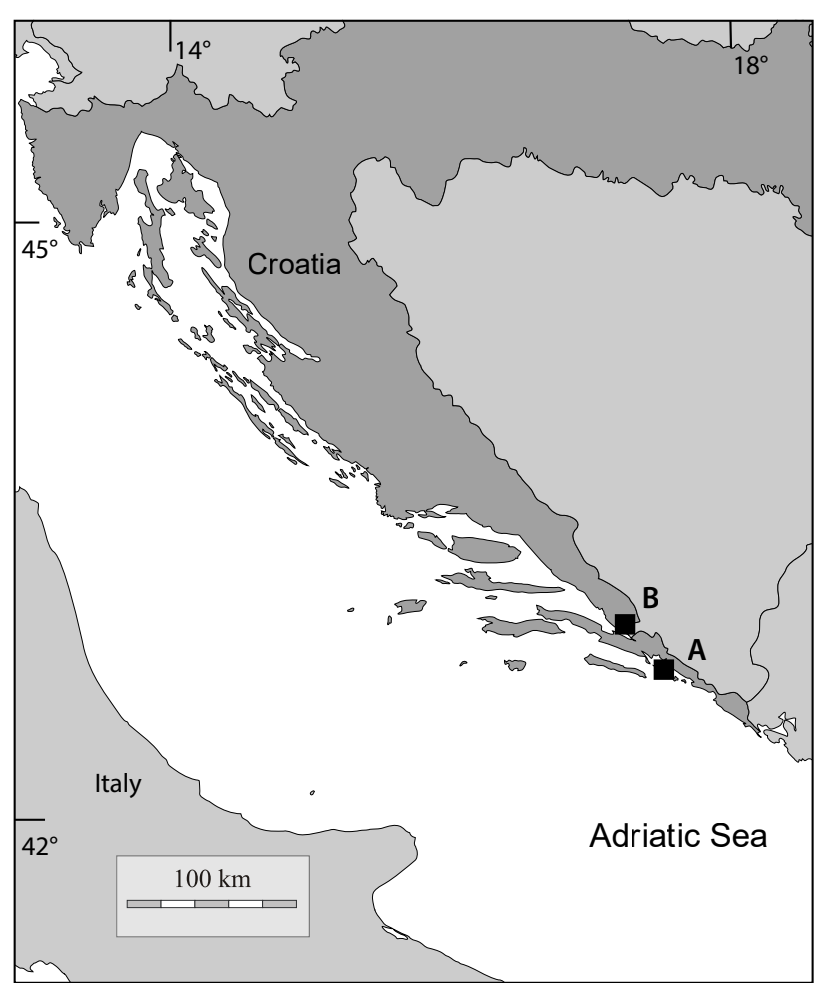

Fig. 1. The site of collection of sampled anguilliform fishes; $\mathrm{A}=$ Elaphiti Islands near Dubrovnik, Croatia (moray and conger); $\mathrm{B}=$ the Neretva River estuary (eel)

Tissue samples preparation for the biochemical analysis. A partial cross-section of the tail region in all specimens, approximately $10 \mathrm{~cm}$ in length from the anus toward the tail tip, was isolated from each fish specimen. The bones were removed and the tail portion (muscle tissue, subdermal fat, and skin) macerated. The samples were taken from this aliquot for all analyses and stored at $-80^{\circ} \mathrm{C}$ in airtight containers until analysed.

Moisture content analysis. Moisture content was determined in samples with a mean mass of $1 \mathrm{~g}$ by standard drying method at $105^{\circ} \mathrm{C}$ until constant mass was attained (Peninal et al. 2012) and calculated as

$$
M_{\%}=100 W_{\mathrm{L}} \cdot W^{-1}
$$

where $M_{\%}$ is \%moisture, $W_{\mathrm{L}}$ is loss of mass, and $W$ is mass of sample.

Ash analysis. The ash content of the sample was analysed as the residue remaining after complete combustion in a muffle furnace (Gerhardt) at $550-600^{\circ} \mathrm{C}$ till the residue turned whitish in colour (Peninal et al. 2012) and calculated as

$$
A_{\%}=W_{\mathrm{A}} \cdot W^{-1}
$$

where $A_{\%}$ is \%ash, $W_{\mathrm{A}}$ is mass of ash, and $W$ is mass of sample.

Crude protein content analysis. Crude protein content was estimated by multiplying the nitrogen content of the dried sample by 6.25 , which was determined by Kjeldahl method as described in Peninal et al. (2012).
Extraction and total lipid analysis. Total lipids were extracted (Varljen et al. 2003) by a chloroform/methanol solvent mixture $(2 \div 1)$ added to samples at a $20 \div 1$ ratio. Samples were centrifuged 3 times for $15 \mathrm{~min}$ at $4000 \mathrm{rpm}$. Intervals between centrifugations were $1 \mathrm{~h}$ at $4^{\circ} \mathrm{C}$. Following this, $4 \mathrm{~mL}$ of $0.034 \% \mathrm{MgCl}_{2} \cdot \mathrm{g}^{-1}$ was added and then incubated overnight at $4^{\circ} \mathrm{C}$. The upper (aqueous) layer was removed, and the lower (organic) layer was rinsed with chloroform/methanol mixture $(2 \div 1)$, and placed into glass tubes. Evaporation of the lower phase provided the total lipid fraction. The solvent was removed in a rotary evaporator under vacuum at $40^{\circ} \mathrm{C}$. These extracts, representing total lipids, were weighed and dissolved once again in a small volume $(1-2 \mathrm{~mL})$ of chloroform/methanol mixture $(2 \div 1)$. The resulting extract of total lipids was stored at $4{ }^{\circ} \mathrm{C}$ until further analysis.

Fatty acid analysis. The fatty acid (FA) profile in total lipid isolates were determined by gas chromatography of the corresponding methyl esters. FA methyl esters were obtained by acid methanolysis of lipid extracts by adding $0.86 \mathrm{~mL}$ benzene and $1.00 \mathrm{~mL} \mathrm{BF3}$ in methanol. A Hewlett Packard HP 5890A capillary gas chromatograph equipped with flame ionization detector (FID) was used. A non-polar capillary column HP Innowax cross-linked polyethyleneglycol (HP-5, $30 \mathrm{~m} \times 0.32 \mathrm{~mm})$, containing $5 \%$ diphenyl and 95\% dimethylsiloxane, was used for analysis. The column temperature was programmed for a linear increase of $4^{\circ} \mathrm{C} \cdot \mathrm{min}^{-1}$ from 150 to $210^{\circ} \mathrm{C}$. The injector and detector temperatures were $250^{\circ} \mathrm{C}$. Nitrogen was used as the carrier gas. Analyses were performed in triplicate. FA methyl esters were identified by comparing their retention times with those of the commercial FA methyl ester standards (GLC 68B Nu-Check-prep, Inc., Elysian, Minnesota). The relative share of each identified FA was calculated automatically.

Statistical analysis. Values are presented as mean \pm standard deviation. The STATISTICA 12.0 software was used for data analysis. Homogeneity was tested by Levene's test. One-way ANOVA was used to test and compare the differences in biochemical parameter and FA compositions. For Post hoc analysis a LSD test was used. The statistical differences were set at $(P \leq 0.05)$.

\section{RESULTS}

Between the three anguilliform species, the moray (MM) and conger $(\mathrm{EC})$ contained more $(P \leq 0.05)$ moisture and ash but less $(P \leq 0.05)$ dry matter than the eel (EE) (Table 1). Moray, conger, and eel had similar amounts of crude protein (Fig. 2). However, major differences $(P \leq 0.05)$ were discovered in the total lipid content of each species (Fig. 2). Interspecies comparison showed the array of lipid content from lowest to highest was $\mathrm{EC}<\mathrm{MM}<\mathrm{EE}$. Moray and conger had a higher protein than lipid content, while eel contained more lipids than protein (Fig. 2).

The specific fatty acid content (Fig. 3) showed that the quantitative ratio of saturated (SFA) to unsaturated fatty acids (UFA) were similar in all three analysed species. 


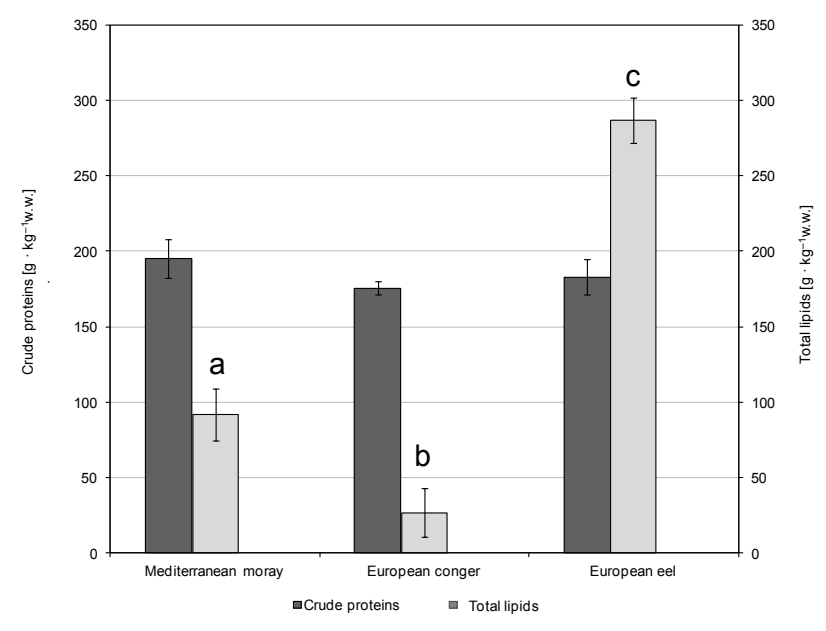

Fig. 2. Crude protein and total lipid content in Mediterranean moray, European conger and European eel

Table 1

Basic body composition parameters of Mediterranean moray, Muraena helena; European conger, Conger conger; and European eel, Anguilla anguilla

\begin{tabular}{cccc}
\hline Parameter & Moray & Conger & Eel \\
\hline Moisture & $699.0 \pm 39.7^{\mathrm{a}}$ & $777.5 \pm 17.5^{\mathrm{b}}$ & $536.5 \pm 5.5^{\mathrm{c}}$ \\
Dry matter & $301.0 \pm 39.7^{\mathrm{a}}$ & $222.5 \pm 17.5^{\mathrm{b}}$ & $463.5 \pm 5.5^{\mathrm{c}}$ \\
Ash & $20.8 \pm 3.9^{\mathrm{a}}$ & $20.7 \pm 0.3^{\mathrm{a}}$ & $14.9 \pm 1.6^{\mathrm{b}}$ \\
\hline
\end{tabular}

Values are mean \pm standard deviation of the mean; values with different superscript letters are statistically significantly different $(P \leq 0.05)$ between the species.

Within UFA, there were important quality differences, as moray and conger contained almost 2 times lower amounts $(P \leq 0.05)$ of monounsaturated fatty acids (MUFA) than eel (Fig. 3). Consequently, the moray and conger had higher $(P \leq 0.05)$ amounts of polyunsaturated fatty acids (PUFA) than the eel (Fig. 3). The array of PUFA concentrations from highest to lowest content within the species were: $\mathrm{EC}>\mathrm{MM}>\mathrm{EE}$, directly reverse than total lipid content. Furthermore, the ratios of $\omega-3 \div \omega-6$ proved that moray contained the highest ratio of $3.14 \div 1$, conger had a ratio of $3.11 \div 1$, while the eel had a reversed ratio of $0.80 \div 1$ (Fig. 4). In addition to the described quantity similarities in SFA and UFA and differences in content of MUFA and PUFA (Fig. 3), prominent differences were found in the qualitative proportions of individual FA (Table 2).

Among SFA, the major fatty acids detected in all species were palmitic- (C16:0), myristic- (C14:0), and stearic acids (C18:0), from highest to lowest. Moray had the highest $(P \leq 0.05)$ proportion of palmitic acid (C16:0) compared to conger, while eel had a slightly lower but significant $(P \leq 0.05)$ proportion than the other two species. Moray had a highest $(P \leq 0.05)$ content of myristic (C14:0), while stearic (C18:0) acid was most abundant in conger $(P \leq 0.05)$.

Among the MUFA, oleic acid (C18:1) was most abundant in all three species, with the highest content in

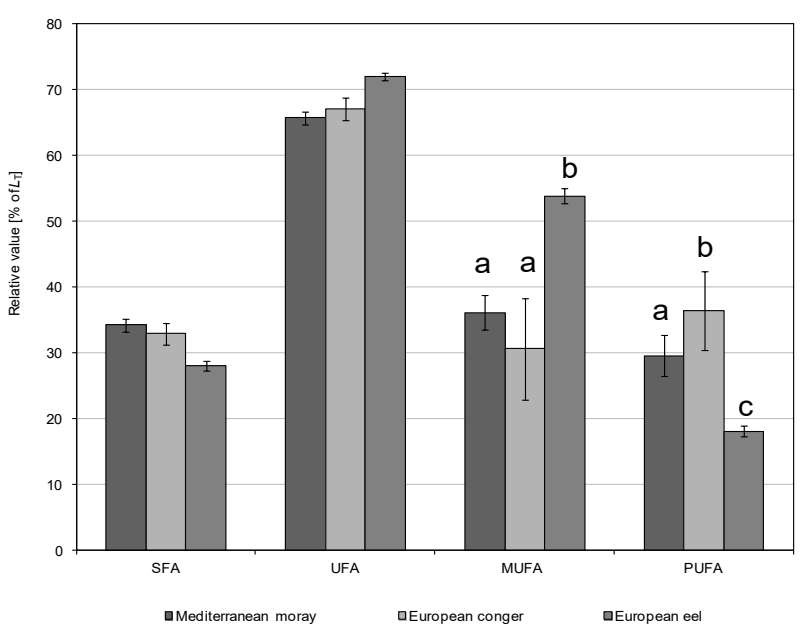

Fig. 3. The content of saturated and unsaturated (monounsaturated and polyunsaturated) fatty acids of Mediterranean moray, European conger eel, and European eel

eel $(P \leq 0.05)$, almost double amount than in other two species. The second most abundant FA was palmitoleic acid $(\mathrm{C} 16: 1)$, which was present in a higher $(P \leq 0.05)$ proportion in moray and eel than in conger. In all three species, individual fatty content of other MUFA was lower than $1.0 \%$, with the exception of eicoasaenoic acid (C20:1 $\mathrm{c}+\mathrm{t}$ ) (Table 2).

Among PUFA, interspecies differences $(P \leq 0.05)$ were prominent. The values of arachidonic acid (ARA; C20:4 n-6) were different $(P \leq 0.05)$ in moray compared to conger and eel. Eicosapentaenoic acid (EPA, C20:5 n-3) was lower $(P \leq 0.05)$ in eel than in moray or conger. The proportion of docosapentaenoic acid (DPA, C22:5 n-3) was higher $(P \leq 0.05)$ in moray than in conger and eel. Content of docosahexaenoic acid (DHA, C22:6 n-3) in moray and conger was significantly higher $(P \leq 0.05)$ than in eel. Moray had approximately 7.6 times and conger had approximately 11 times more DHA than eel. Amongst the three species conger had the highest value of DHA but only by approximately 1.5 higher than moray. Table 3 shows the individual FA bioconversion capacity, a ratio between substrate and product within biochemical FA synthesis pathways. Moray and conger had significantly higher $(P \leq 0.05) \mathrm{EPA} \div \alpha \mathrm{LNA}$ and $\mathrm{DHA} \div \mathrm{DPA}$ ratio and significantly lower $(P \leq 0.05) \mathrm{DPA} \div$ EPA ratio than the eel.

\section{DISCUSSION}

The objective of this study was to compare the biochemical differences in the fatty acid profile in three related anguilliform species.

Basic biochemical analysis of moisture content showed that moray and conger had higher moisture content than eel. This can be explained by physiology of osmoregulation in marine environment, since marine fish tend to retain water to prevent permanent physiological dehydration in salt water. Also as a consequence of marine origin, moray and conger had higher amounts of inorganic 
Table 2

Fatty acid contents in Mediterranean moray, Muraena helena; European conger, Conger conger; and European eel, Anguilla anguilla

\begin{tabular}{|c|c|c|c|c|}
\hline \multirow{2}{*}{ Fatty acid } & & \multicolumn{3}{|c|}{ Fatty acid contents $[\%$ of total lipids $]$} \\
\hline & & Moray & Conger & Eel \\
\hline C10:0 & decanoic (capric) & $0.022 \pm 0.003$ & $0.037 \pm 0.020$ & $0.008 \pm 0.002$ \\
\hline C11:0 & undecanoic (undecylic) & $0.083 \pm 0.036$ & $0.318 \pm 0.171$ & $0.021 \pm 0.005$ \\
\hline C11:1 & undecenoic & $00.00 \pm 0.00$ & $00.00 \pm 0.00$ & $00.00 \pm 0.00$ \\
\hline $\mathrm{C} 12: 0$ & dodecanoic (lauric) & $0.109 \pm 0.021$ & $0.074 \pm 0.002$ & $0.203 \pm 0.023$ \\
\hline $\mathrm{C} 12: 1$ & dodecenoic (dodecylic) & $0.005 \pm 0.002$ & $00.00 \pm 0.00$ & $0.050 \pm 0.003$ \\
\hline $\mathrm{C} 13: 0$ & tridecanoic (tridecylic) & $0.062 \pm 0.009$ & $0.046 \pm 0.001$ & $0.040 \pm 0.002$ \\
\hline C13:1 & tridecenoic & $0.031 \pm 0.006$ & $0.023 \pm 0.001$ & $0.088 \pm 0.007$ \\
\hline C14:0 & tetradecanoic (myristic) & $4.978 \pm 0.357^{\mathrm{a}}$ & $3.270 \pm 1.003^{\mathrm{b}}$ & $3.450 \pm 0.064^{\mathrm{b}}$ \\
\hline C14.1 & tetradecenoic (myristoleinic) & $0.262 \pm 0.035^{\mathrm{a}}$ & $0.118 \pm 0.071^{\mathrm{b}}$ & $0.224 \pm 0.006^{\mathrm{a}}$ \\
\hline $\mathrm{C} 15: 0$ & pentadecanoic (pentadecylic) & $0.658 \pm 0.076^{\mathrm{a}}$ & $0.611 \pm 0.002^{\mathrm{a}}$ & $0.337 \pm 0.011^{\mathrm{b}}$ \\
\hline C15:1 & pentadecenoic & $00.00 \pm 0.00$ & $00.00 \pm 0.00$ & $00.00 \pm 0.00$ \\
\hline C16:0 & hexadecanoic (palmitic) & $22.238 \pm 0.766^{\mathrm{a}}$ & $20.376 \pm 0.597^{b}$ & $18.711 \pm 0.242^{\mathrm{c}}$ \\
\hline $\mathrm{C} 16: 1 \mathrm{c}+\mathrm{t}$ & hexadecenoic (palmitoleic) & $8.388 \pm 0.884^{\mathrm{a}}$ & $5.673 \pm 1.956^{\mathrm{b}}$ & $8.983 \pm 0.122^{\mathrm{a}}$ \\
\hline $\mathrm{C} 17: 0$ & heptadecanoic (margaric) & $0.677 \pm 0.092^{\mathrm{a}}$ & $0.646 \pm 0.091^{\mathrm{a}}$ & $0.517 \pm 0.004^{\mathrm{b}}$ \\
\hline $\mathrm{C} 17: 1$ & heptadecenoic & $00.00 \pm 0.00$ & $00.00 \pm 0.00$ & $00.00 \pm 0.00$ \\
\hline C18:0 & oktadecanoic (stearic) & $4.562 \pm 0.272^{\mathrm{a}}$ & $6.661 \pm 1.747^{b}$ & $4.299 \pm 0.001^{\mathrm{a}}$ \\
\hline $\mathrm{C} 18: 1 \mathrm{c}+\mathrm{t}$ & oktadecenoic (oleic, eladic) & $24.427 \pm 1.770^{\mathrm{a}}$ & $22.684 \pm 5.381^{\mathrm{a}}$ & $41.765 \pm 0.998^{\mathrm{b}}$ \\
\hline$C 18: 2 c+t, n-6$ & oktadekadienoic (LA, linoleic) & $1.149 \pm 0.167^{\mathrm{a}}$ & $1.679 \pm 0.052^{\mathrm{a}}$ & $2.945 \pm 0.380^{\mathrm{b}}$ \\
\hline $\mathrm{C} 18: 3 \mathrm{c}, \mathrm{n}-6$ & oktadekatrienoic (gamma-linolenic) & $0.264 \pm 0.008^{\mathrm{a}}$ & $0.158 \pm 0.013^{\mathrm{a}}$ & $0.127 \pm 0.023^{\mathrm{b}}$ \\
\hline $\mathrm{C} 18: 3 \mathrm{c}, \mathrm{n}-3$ & oktadekatrienoic (LNA, alpha-linolenic) & $0.614 \pm 0.095^{\mathrm{a}}$ & $0.578 \pm 0.054^{\mathrm{a}}$ & $1.349 \pm 0.260^{\mathrm{b}}$ \\
\hline C18:2 CLA & conjugated linoleic (CLA) & $00.00 \pm 0.00$ & $00.00 \pm 0.00$ & $00.00 \pm 0.00$ \\
\hline C19:0 & nonadecanoic & $0.184 \pm 0.020^{\mathrm{a}}$ & $0.242 \pm 0.053^{\mathrm{b}}$ & $0.111 \pm 0.007^{\mathrm{a}}$ \\
\hline $\mathrm{C} 19: 1 \mathrm{c}+\mathrm{t}$ & nonadecenoic & $0.131 \pm 0.026^{\mathrm{a}}$ & $0.175 \pm 0.003^{\mathrm{a}}$ & $0.350 \pm 0.016^{\mathrm{b}}$ \\
\hline $\mathrm{C} 20: 0$ & eicosanoic (arachidic) & $0.289 \pm 0.020^{\mathrm{a}}$ & $0.229 \pm 0.004^{\mathrm{a}}$ & $0.189 \pm 0.011^{\mathrm{b}}$ \\
\hline $\mathrm{C} 20: 1 \mathrm{c}+\mathrm{t}$ & eicosaenoic & $1.888 \pm 0.178^{\mathrm{a}}$ & $1.070 \pm 0.139^{\mathrm{a}}$ & $2.229 \pm 0.281^{\mathrm{b}}$ \\
\hline$C 20: 2$ n-6 & eicosadienoic & $0.478 \pm 0.058^{\mathrm{a}}$ & $0.451 \pm 0.054^{\mathrm{a}}$ & $1.252 \pm 0.126^{\mathrm{b}}$ \\
\hline$C 20: 3 n-6$ & eicosatrienoic (homo- $\gamma$-linolenic) & $0.251 \pm 0.011^{\mathrm{a}}$ & $0.172 \pm 0.002^{b}$ & $0.532 \pm 0.012^{\mathrm{c}}$ \\
\hline $\mathrm{C} 21: 0$ & heneicosanoic & $0.086 \pm 0.019^{\mathrm{a}}$ & $0.047 \pm 0.005^{b}$ & $0.012 \pm 0.003^{\mathrm{b}}$ \\
\hline C20:4 n-6 & eicosatetraenoic(ARA, arachidonic) & $3.138 \pm 0.356^{\mathrm{a}}$ & $4.165 \pm 1.256^{\mathrm{b}}$ & $3.884 \pm 0.149^{b}$ \\
\hline$C 20: 3 n-3$ & eicosatrienoic & $0.195 \pm 0.008^{\mathrm{a}}$ & $0.145 \pm 0.003^{\mathrm{a}}$ & $0.252 \pm 0.025^{\mathrm{b}}$ \\
\hline$C 20: 5 n-3$ & eicosapentaenoic (EPA) & $3.921 \pm 0.445^{\mathrm{a}}$ & $3.604 \pm 0.304^{\mathrm{a}}$ & $2.214 \pm 0.266^{\mathrm{b}}$ \\
\hline $\mathrm{C} 22: 0$ & docosanoic (behenic) & $0.217 \pm 0.056^{\mathrm{a}}$ & $0.254 \pm 0.034^{\mathrm{a}}$ & $0.079 \pm 0.002^{\mathrm{b}}$ \\
\hline $\mathrm{C} 22: 1 \mathrm{c}+\mathrm{t}$ & docosaenoic (eruca, brazidinic) & $0.392 \pm 0.096^{\mathrm{a}}$ & $0.195 \pm 0.069^{b}$ & $0.128 \pm 0.007^{\mathrm{b}}$ \\
\hline $\mathrm{C} 22: 2 \mathrm{n}-6$ & docosadienoic & $0.061 \pm 0.010^{\mathrm{a}}$ & $0.046 \pm 0.002^{\mathrm{b}}$ & $0.082 \pm 0.004^{\mathrm{b}}$ \\
\hline $\mathrm{C} 23: 0$ & docotriosaenoic & $0.035 \pm 0.011^{\mathrm{a}}$ & $0.023 \pm 0.005^{\mathrm{b}}$ & $0.015 \pm 0.002^{\mathrm{c}}$ \\
\hline C22:4 n-6 & docosatetraenoic & $1.176 \pm 0.080^{\mathrm{a}}$ & $0.947 \pm 0.181^{\mathrm{b}}$ & $1.270 \pm 0.055^{\mathrm{a}}$ \\
\hline $\mathrm{C} 22: 3 \mathrm{n}-3$ & docosatrienoic & $0.016 \pm 0.003$ & $00.00 \pm 0.00$ & $0.008 \pm 0.002$ \\
\hline$C 22: 5 n-6$ & docosapentaenoic & $0.851 \pm 0.143^{\mathrm{a}}$ & $1.017 \pm 0.144^{\mathrm{b}}$ & $0.353 \pm 0.038^{\mathrm{c}}$ \\
\hline$C 22: 5 n-3$ & docosapentaenoic (DPA) & $2.634 \pm 0.158^{\mathrm{a}}$ & $1.911 \pm 0.014^{\mathrm{b}}$ & $1.895 \pm 0.165^{\mathrm{b}}$ \\
\hline $\mathrm{C} 24: 0$ & tetracosaenoic (lignocerinic) & $0.064 \pm 0.025^{\mathrm{a}}$ & $0.101 \pm 0.002^{\mathrm{b}}$ & $0.024 \pm 0.002^{\mathrm{a}}$ \\
\hline $\mathrm{C} 22: 6 \mathrm{n}-3$ & docosahexaenoic (DHA) & $14.848 \pm 2.429^{\mathrm{a}}$ & $21.536 \pm 4.210^{\mathrm{b}}$ & $1.955 \pm 0.089^{\mathrm{c}}$ \\
\hline $\mathrm{C} 24: 1$ & tetracosaenoic (nervonic) & $0.624 \pm 0.075^{\mathrm{a}}$ & $0.729 \pm 0.105^{\mathrm{a}}$ & $0.058 \pm 0.006^{b}$ \\
\hline
\end{tabular}

Values are mean \pm standard deviation of the mean; values with different superscript letters are statistically significantly different $(P \leq 0.05)$ between the species; $\mathrm{c}=\mathrm{c}$-cis form, $\mathrm{t}=$ trans form.

compounds than eel, as seen indirectly by the ash content. the presently reported results (Table 1), although in some The results of moray (Table 1) were consistent with single species i.e., tropical Conger cinereus Rüppell, 1830 (see literature reports of Gymnothorax sp., which had a dry Goodman-Lowe et al. 2009) it was reported to have a matter content of $28.3 \%-34.8 \%$ and ash content of $2.7 \%-$ lower moisture content and ash content than C. conger in $4.5 \%$ (Goodman-Lowe et al. 1999). For conger it was our study. For eel, data in Table 1 were also consistent reported that it had a moisture content of approximately with reported ranges for moisture of $47.8 \%-77.7 \%$ and $77 \%$ (Lombardi et al. 2006), which was consistent with dry matter ranging from $32.9 \%$ to $45.3 \%$ (Boëtius and 

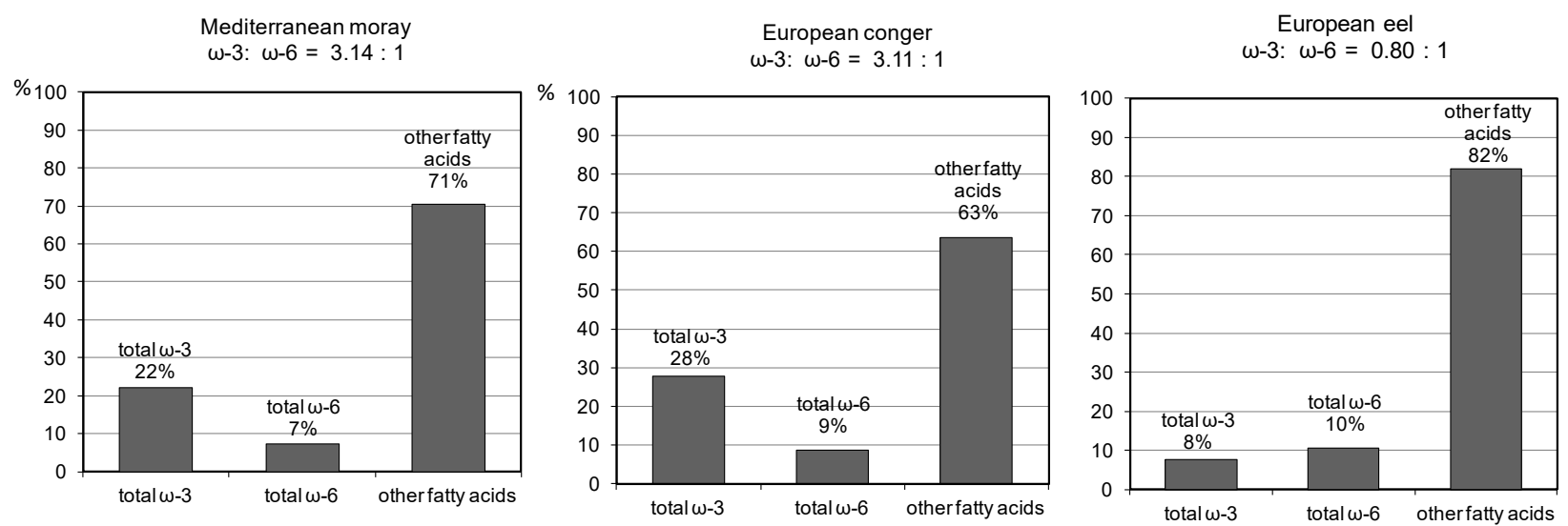

Fig. 4. The ratios of $\omega-3$ and $\omega-6$ content in total extracted lipids in Mediterranean moray, European conger eel and European eel

Boëtius 1985, Degani et al. 1986) which was also similar for other eel species (Oku et al. 2009, Rupia et al. 2014).

The main results of this study show, however, that all three species had similar amounts of crude protein but had prominent interspecies differences in total lipid content (Fig. 2). The total lipid content in moray and conger did not exceed the crude proteins content, while in eel total lipid exceeded the crude protein content. Moray and conger had $4-10$-fold lower $(P \leq 0.05)$ wet body mass (w.w.) of total lipid than the eel. With lowest lipid level of about 4-fold lower than the moray and about 10-fold lower than the eel, conger was the leanest species analysed in this study. No record on total lipid reports were found for moray, only the results of total lipid in the tropical genus Gymnothorax sp. were reported to be $10.9 \%$ $14.1 \%$ w.w. (Goodman-Lowe et al. 2009). For conger, the results were within ranges recorded for Adriatic Sea fish which were between $3.7 \%$ and $3.8 \%$ w.w. of total lipid (Varljen et al. 2003, Lombardi et al. 2006), it would be interesting if northern or Atlantic populations would have similar ranges. The reference values for eel were also in accordance with the presently reported protein $\div$ lipid ratios (Lie et al. 1990, Mazzeo et al. 2010, Ersoy 2011, El Oudiani and Hechmi 2013). The ratio differences between protein and lipids were slightly higher here than recorded in Boëtius and Boëtius (1985).

We concluded that in the phylogenetic and taxonomic contexts the total lipid content recorded in this study, beside trophic influence, is also a biological trait of each family - the Muraenidae and the Congridae, because the

Estimate of product/substrate content along Omega-3 bioconversion pathway in Mediterranean moray, Muraena helena; European conger, Conger conger; and European eel, Anguilla anguilla

\begin{tabular}{lccc}
\hline \multicolumn{1}{c}{ Ratio } & Moray & Conger & Eel \\
\hline EPA/ $\alpha-L N A$ & $6.39^{\mathrm{a}}$ & $6.23^{\mathrm{a}}$ & $1.64^{\mathrm{b}}$ \\
DPA-n3/EPA & $0.61^{\mathrm{a}}$ & $0.53^{\mathrm{a}}$ & $0.85^{\mathrm{b}}$ \\
DHA/DPA-n3 & $5.63^{\mathrm{a}}$ & $11.27^{\mathrm{b}}$ & $1.03^{\mathrm{c}}$
\end{tabular}

Values with different superscript letters are statistically significantly different $(P \leq 0.05)$ between the species. results were consistent with the earlier mentioned (related) Conger sp. species. However, one should be careful in comparison because lipid contents can be quite variable between tropical and temperate moray species (as it is the case for moisture content of conger).

The main reason for the differences in total lipid content is probably a trophic status of the three species. As we noted earlier, moray consumed less crustaceans and more fish than conger (Matić-Skoko et al. 2012, 2014). Eel, coming from brackish water, probably consumed completely different diet and different taxa. Additionally, ecophysiology of thermal adaptation to the seasonal temperature variations of inland waters might influence more lipid storage than in a thermally stable marine environment. Variations in total lipid content and the profile of different lipid types are common in cold adaptations among fish and other vertebrates (Palmerini et al. 2009, Heffer-Lauc et al. 2010, Mazzeo et al. 2010, Ghazali et al. 2013). Also, lipids tend to accumulate in eel prior to spawning migration (Dębowska et al. 2015) but also tend to increase with growth (Degani et al. 1986). We could only guess whether any growth phase of moray and conger would follow the same trend as noted in Dębowska et al. (2015) and Degani et al. (1986) especially in the first years of growth, in this study such correlation was impossible since all animals were adults above 5 up to 7 years of age (Matić-Skoko at al. 2012, 2014). Nevertheless, fish with more than $5 \%$ lipid content are generally regarded as fatty (Oku et al. 2009, Peninal et al. 2012) thus all three species can be considered as such. In the introduction we explained a special interest in total lipid content in terms of ecotoxicological studies of bioaccumulation. Results indicate that moray can be regarded as species of high lipophilic potential alongside certain conger and eel species (Arai and Takeda 2012). Based on lipid compositions and xenobiotic accumulation and high trophic status we would recommend moray as bioindicator organism in ecotoxicological studies of local pollutant accumulation in benthic communities.

Amongst the individual FA analysed in this study, the quantitative SFA profiles (Fig. 3) of all three species were similar and corresponded to the usual ranges in vertebrates 
(Varljen et al. 2003, Heffer-Lauc et al. 2010). Published sources report SFA values of $33.7 \%$ for conger (Varljen et al. 2003) and 27.4\%-28.2\% for eel (Lie et al. 1990, Mazzeo et al. 2010, Ersoy 2011, El Oudiani and Hechmi 2013, Baeza et al. 2014), which is similar to our results.

On the other hand, qualitative SFA, MUFA, and PUFA content and profiles were species specific (Fig. 3, Table 2). Qualitatively, slight differences in the content of individual SFA can be attributed as the characteristic and unique "FA fingerprint" among the analysed species. The palmitic (C16:0), stearic (C18:0), and myristic (C14:0) ratios were species specific (for example myristic for the moray). In contrast among MUFA, oleic (C18:1) was characteristically higher in eel.

Total PUFA content was prominently different, higher in moray and conger, with DHA as the main contributor. Between those two species, conger showed the highest PUFA concentrations, though moray showed the most qualitatively favourable ratios of important $\omega$ FA (Fig. 4). Individual FA percentage ratios of total lipid (Table 2) for conger were within similar ranges as in Varljen et al. (2003) and Lombardi et al. (2006). For eel results (Table 2) corresponded within ranges reported in literature. In the references, the particular $\%$ total lipid ranges for wild eel $(31.1-48.2 \mathrm{~cm})$ were for example $0.49 \%-1.6 \%$ (for $\alpha$-LNA); $1.41 \%-4.86 \%$ (for EPA); $1.10 \%-3.1 \%$ (for DPA); and $1.2 \%-4.8 \%$ (for DHA), but other FA correspond by ranges as well (Lie et al. 1990, Mazzeo et al. 2010, Ersoy 2011, El Oudiani and Hechmi 2013).

We believe that these observed FA differences are a direct consequence of trophic ecology since eel feed prey of freshwater origin, and moray and conger feed prey of marine origin. It is well known that FA composition of fish reflects dietary FA. Although in fish variations of FA are dependent on the season, for the purpose of this study we used the same season for all three species at the end of summer when the accumulation of fatty tissue reach higher levels. Therefore, FA composition of wild fish depends on area where fish were caught. Differences between freshwater and marine environment greatly affect FA composition of anguilliform species, but with possible contribution of intrinsic bioconversion capacity of fish. Between the fish from the same environment, trophic differences were probably also the major basis for disparity in PUFA and $\omega-3$ between moray and conger. Following the pray species list in Matić-Skoko et al. $(2012,2014)$, we tried to find literature values on lipid profiles for each consumed species (fish, shellfish, and crustacean) and correlate them to the results here. For majority of consumed species such data on FA composition do not exist and measuring each pray species listed would surpass the limits of this work. Interesting was the presence of cannibalism in conger and its absence in moray (Matić-Skoko et al. 2012, 2014), thus the consumption of PUFA and $\omega-3$ rich prey (conger by cannibalising its conspecifics trophicaly re-converts $\omega-3)$, contributes to an even higher content in that species, although moray consumes conger as well.
Most interesting was the observation of higher amount of $\alpha$-linolenic ( $\alpha$-LNA, C18:3 n-3) and lower amounts of EPA (C20:5 n-3) and DHA (C22:6 n-3) in eel and the reverse trend recorded in moray and conger. It is generally accepted that $\alpha$-LNA and LA are essential FA and cannot be synthesized in vertebrates, thus their content is dietary dependent and that freshwater and terrestrial organisms have more dietary available $\alpha$-LNA and LA. Freshwater and terrestrial organisms have higher degree of utilization of biosynthesis pathways and bioaccumulation of $\omega-3$ FA, more than marine fish which are surrounded by abundant dietary sources of $\omega-3$ FA (Tocher 2003, Hixon et al. 2015, Castro et al. 2016). This is in line with observed higher $\alpha$-LNA and lower EPA and DHA in eel compared to marine species (Table 2). However, vertebrates, including fish, can convert $\alpha$-LNA and LA to ARA, EPA, and DHA to a certain extent. Fish elongase and $\Delta 5$ - and $\Delta 6$-desaturase biochemically elongate and convert the precursor FA $\alpha$-LNA to EPA and then to DPA, which is then converted to DHA in the liver and intestine (Boldsen et al. 2013, Damsteegt et al. 2014, Xue et al. 2014, Kabeya et al. 2015). The degree of efficacy in various organisms is a subject of broad discussions, especially since the $\omega-3$ FA DHA synthesis in marine fish is believed to be low or non existing. These general paradigms are more complex than it appears and are dependent on the levels of FA elongase (Elovl 2 and 5 mainly) and FA desaturase (Fads 2 mainly) gene expression and $\Delta 5, \Delta 6$, and recently demonstrated $\Delta 8$ and $\Delta 4$ activity in some marine species (Tocher 2003, Monroig et al. 2011, Castro et al. 2016). The ratios of FA (Table 3 ) indirectly indicate that in moray and conger alongside synthesis chain from $\alpha$-LNA to DHA, there are differences in amounts of precursor and substrate molecules than in the eel. Approximate ratios show that there is 6 -fold more EPA than $\alpha$-LNA in moray and conger, and only 1.64-fold in eel, or 5.63-fold and 11.27-fold more DHA than DPA in moray and conger respectively, and only 1.03-fold more in eel (Table 3 ). Literature data ranges of total lipids for eel (Lie et al. 1990, Mazzeo et al. 2010, Ersoy 2011, El Oudiani and Hechmi 2013) were similar, amounting to $1.83 \%-4.86 \%$ (for $\mathrm{EPA} / \alpha-\mathrm{LNA}$ ); $0.57 \%-0.85 \%$ (for DPA-n3/EPA); and $0.57 \%-1.69 \%$ (for DHA/DPA-n3). Furthermore, for example, in various tuna species their oils (of particular body parts) have high contents of DHA (25\%-36\% total lipid, depending on species) and high ratios of DHA $\div$ EPA (5.8-11.3). That these ratios were higher than the DHA $\div$ EPA ratio in stomach contents (up to 4 ) of devoured food in tuna, a probable consequence of selective metabolism (bioconversion and $\beta$ oxidations) in this fish type as explained by (Tocher 2003). In this study, DHA EPA in moray was approximately 3.7 , in conger 5.9, and in eel only 0.8 . Similar ratios, if calculated from literature data for DHA $\div$ EPA in conger was 9.6 in Varljen et al. (2003), and in eel in the range between 0.5-1.3 (Lie et al. 1990, Mazzeo et al. 2010, Ersoy 2011, El Oudiani and Hechmi 2013). Thus, based on these high indices, similar as in tuna, it should be at least hypothesized whether the moray and conger, compared to eel, have different 
intrinsic bioconversion and bioaccumulation capacity for EPA and DHA, beside dietary intake (which is certain only for essential dietary $\alpha$-LNA that has to be ingested).

Bioconversion potential is largely known in anadromous fishes (i.e., Atlantic salmon) and for a catadromous fish (e.g., Japanese eel) possessing Fads 2 and Elovl 5, it was reported that its bioconversion activity of $\Delta 6 \div \Delta 8$ is similar to Atlantic salmon but activity of enzymes towards $\mathrm{C} 18$ to $\mathrm{C} 20$ resembles general paradigms of marine species. The $\mathrm{Fad} \div$ Elovl expressed in yeast showed \%conversion rates of elongase and desaturase from $\alpha$-LNA to $\mathrm{C} 20: 4 \mathrm{n}-3$ by $\Delta 6$ to be $\approx 65 \%$ and by $\Delta 8$ to be $\approx 6 \%$ and elongase rates from EPA to DPA $\approx 30 \%$ but $0 \%$ conversion rates of elongase and desaturase from DPA toward DHA, which is a mentioned marine fish paradigm (Wang et al. 2014). If the future studies show that these pathways are equally efficient in all three eel species, then the differences in the FA compositions have to be attributed to the trophic physiology and prey composition as assumed at the beginning of this study. We leave the open hypothesis that high DHA content, might also be intrinsically biosynthesized in moray and conger, although they probably have bioconversion activity of Fads $2 \Delta 6 \div \Delta 8$ and Elovl 5 , inefficient toward synthesis of 22n-3 PUFA. Interestingly, Giudetti et al. (2001) demonstrated that in eel elongase activities, in active pathway parts, under certain circumstances exceed 2-fold the activity of mammalian elongase enzymes. Thus, the right question from Tables 2 (FA contents) and Table 3 (FA ratios) and the discussion on elongase and desaturase pathways is how much more potent these system are in moray or conger compared to eel, other fish, mammals or other vertebrates. No similar studies were made. Evolution of elongase systems in teleost fish, its genetic background or their possible exploitation and application is extensively studied and important, especially since natural nutritional and industrial $\omega-3$ FA sources are diminished or overexploited (i.e., cod fish oil etc.) (Leaver et al. 2008, Castro et al. 2016).

In conclusion, this study showed that both moray and conger were less fatty than eel but had higher $\omega$-FA content. As hypothesized on trophic studies of these three species, their lipid profiles were species specific. The results also indirectly pointed to differences in the physiological utilization of biochemical elongation and desaturation pathways and differences in FA bioconversion and bioaccumulation. This topic should be further investigated among anguilliform, especially the genetic background or its possible exploitation and application.

We hope that the results brought here would contribute to this broader content and draw focus on moray and conger to be included in the studies on evolution of elongase and desaturase systems in teleost fish.

\section{ACKNOWLEDGMENT}

We are indebted to the professional fishermen L. Burmas, H. Turković, and M. Oberan for their help in providing fish samples, to M. Lujo, K. Tutek-Primorac and I. Barać for technical support and to the captain Ž. Baće of the ship Baldo Kosić II. We are grateful to the Institute of Food Research EMONA Ljubljana, Dr. Mateja Vendarmin for help with the methodology of FA determination. This study was funded by Ministry of Science, Education and Sports of the Republic of Croatia, projects BIOECOCROMON-Bilateral international project on biology of South Adriatic organisms and projects grant number no. 275-001 0501-0856.

\section{REFERENCES}

Aitzetmüller K., Taraschewski H., Filipponi C., Werner G., Weber N. 1994. Lipids of fish parasites and their hosts: Fatty acids of phospholipids of Paratenuisentis ambiguus and its host eel (Anguilla anguilla). Comparative Biochemistry and Physiology Part B: Comparative Biochemistry 109 (2-3): 383-389. DOI: 10.1016/0305-0491(94)90021-3

Anastasopoulou A., Mytilineou CH., Lefkaditou E., Kavadas S., Bekas P., Smith C.J., Papadopoulou K.N., Christides G. 2013. The diet and feeding ecology of Conger conger (L. 1758) in the deep waters of the eastern Ionian Sea. Mediterranean Marine Science 14 (2): 365-368.

DOI: $10.12681 / \mathrm{mms} .479$

Anonymous 2006. Odluka o proglašenju zakona o zaštiti životinj. [Act on animal welfare.] Narodne novine, službeni list Republike Hrvatske (13.12.2006) NN135 (3045). [In Croatian.]

Anonymous 2010. Directive 2010/63/EU of the European Parliament and of the Council of 22 September 2010 on the protection of animals used for scientific purposes (Text with EEA relevance). Official Journal of the European Union (20.10.2010) L 276/33.

Arai T., Takeda A. 2012. Differences in organochlorine accumulation accompanying life history in the catadromous eel Anguilla japonica and the marine eel Conger myriaster. Ecotoxicology 21 (4): 1260-1271. DOI: $10.1007 / \mathrm{s} 10646-012-0881-8$

Baeza R., Mazzeo I., Vílchez M.C., Gallego V., Peñaranda D.S., Pérez L., Asturiano J.F. 2014. Effect of thermal regime on fatty acid dynamics in male European eels (Anguilla anguilla) during hormonallyinduced spermatogenesis. Aquaculture 430: 86-97.

DOI: 10.1016/j.aquaculture.2014.03.045

Baeza R., Mazzeo I., Vílchez M.C., Gallego V., Peñaranda D.S., Pérez L., Asturiano J.F. 2015a. Relationship between sperm quality parameters and the fatty acid composition of the muscle, liver and testis of European eel. Comparative Biochemistry and Physiology Part A: Molecular and Integrative Physiology 181: 79-86. DOI: $10.1016 /$ j.cbpa.2014.11.022

Baeza R., Peñaranda D.S., Vílchez M.C., Tveiten H., Pérez L., Asturiano J.F. 2015b. Exploring correlations between sex steroids and fatty acids and their potential roles in the induced maturation of the male European eel. Aquaculture 435: 328-335.

DOI: $10.1016 /$ j.aquaculture.2014.10.016 
Betancor M.B., Olsen R.E., Solstorm D., Skulstad O.F., Tocher D.R. 2016. Assessment of a land-locked Atlantic salmon (Salmo salar L.) population as a potential genetic resource with a focus on long-chain polyunsaturated fatty acid biosynthesis. Biochimica et Biophysica Acta 1861 (3): 227-238.

DOI: 10.1016/j.bbalip.2015.12.015

Boerrigter J.G.J., Manuel R., van den Bos R., Roques J.A.C., Spanings T., Flik G., van de Vis H.W. 2015. Recovery from transportation by road of farmed European eel (Anguilla anguilla). Aquaculture Resources 46 (5): 1248-1260. DOI: 10.1111 /are. 12284

Boëtius I., Boëtius J. 1985. Lipid and protein content in Anguilla anguilla during growth and starvation. Dana 4: 1-17.

Boldsen M.M., Norin T., Malte H. 2013. Temporal repeatability of metabolic rate and the effect of organ mass and enzyme activity on metabolism in European eel (Anguilla anguilla). Comparative Biochemistry and Physiology Part A: Molecular and Integrative Physiology 165 (1): 22-29.

DOI: $10.1016 /$ j.cbpa.2013.01.027

Butts I.A.E., Baeza R., Støttrup J.G., KrügerJohnsen M., Jacobsen C., Pérez L., Asturiano J.F., Tomkiewicz J. 2015. Impact of dietary fatty acids on muscle composition, liver lipids, milt composition and sperm performance in European eel. Comparative Biochemistry and Physiology Part A: Molecular and Integrative Physiology 183: 87-96.

DOI: $10.1016 /$ j.cbpa.2015.01.015

Castro L.F.C., Tocher D.R., Monroig O. 2016. Longchain polyunsaturated fatty acid biosynthesis in chordates: Insights into the evolution of Fads and Elovl gene repertoire. Progress in Lipid Research 62: 25-40. DOI: $10.1016 /$ j.plipres.2016.01.001

Damsteegt E.L., Mizuta H., Ozaki Y., Hiramatsu N., Todo T., Hara A., Ijiri S., Adachi S., Lokman P.M. 2014. Development and partial characterisation of an antiserum against apolipoprotein B of the short-finned eel, Anguilla australis. Comparative Biochemistry and Physiology Part B: Biochemistry and Molecular Biology 184 (5): 589-599.

DOI: $10.1007 / \mathrm{s} 00360-014-0821-4$

Dębowska M., Nowosad J., Targońska K., Żarski D., Bilas M., Luczyńska J., Kucharczyk D. 2015. Fecundity of migrating European eel (Anguilla anguilla) from Polish waters. Italian Journal of Animal Science 14 (3): 566-570.

DOI: $10.4081 /$ ijas.2015.3898

Degani G., Hahamu H., Levanon D. 1986. The relationship of eel Anguilla anguilla (L.) body size, lipid protein, glucose, ash, moisture composition and enzyme activity (aldolase). Comparative Biochemistry and Physiology Part A: Comparative Physiology 84 (4): 739-745.

DOI: 10.1016/0300-9629(86)90398-1

Đikić D., Lisičíć D., Matić-Skoko S., Tutman P., Skaramuca D., Franić Z., Skaramuca B. 2013.
Comparative hematology of wild Anguilliformes (Muraena helena, L. 1758, Conger conger, L. 1758 and Anguilla anguilla L. 1758). Animal Biology 63 (1): 77-92.

DOI: $10.1163 / 15707563-00002395$

Đikić D., Mojsović Ćuić A., Jurak G., Lasić D., Skaramuca D., Matić-Skoko S., Tutman P., Bošnir J., Franjević D., Franić Z., Fuchs R., Skaramuca B. 2013. Organochlorine pesticides in Muraena helena L. 1758 from the eastern Adriatic Sea. Journal of Applied Ichthyology 30 (3): 496-501.

DOI: $10.1111 /$ jai.12385

Ekanayake P.M., Park G.T., Lee Y.D., Kim S.J., Jeong S.C., Lee J. 2005. Antioxidant potential of eel (Anguilla japonica and Conger myriaster) flesh and skin. Journal of Food Lipids 12 (1): 34-47. DOI: $10.1111 / \mathrm{j} .1745-4522.2005 .00004 . \mathrm{x}$

El Oudiani S., Hechmi M. 2013. Seasonal variation of fatty acids composition in European eel muscles from the North East of Tunisia: Bizerte Lagoon. Advances in Bioresearch 14 (3): 14-21.

Ersoy B. 2011. Effects of cooking methods on the proximate, mineral and fatty acid composition of European eel (Anguilla anguilla). International Journal of Food Science and Technology 46 (3): 522-527. DOI: $10.1111 /$ j.1365-2621.2010.02546.x

Geay F., Tinti E., Mellery J., Michaux C., Larondelle Y., Perpète E., Kestemont P. 2016. Cloning and functional characterization of $\Delta 6$ fatty acid desaturase (FADS2) in Eurasian perch (Perca fluviatilis). Comparative Biochemistry and Physiology Part B: Biochemistry and Molecular Biology 191: 112-125. DOI: 10.1016/j.cbpb.2015.10.004

Ghazali N., Boussoufa D., Navarro J.C., El Cafsi M. 2013. Lipid and fatty acid variations in muscle tissues of the 'yellow' stage of the European eel (Anguilla anguilla) during short-term adaptation to freshwater and seawater under food deprivation. Marine and Freshwater Behaviour and Physiology 45 (6): 385-395. DOI: $10.1080 / 10236244.2013 .774548$

Giudetti A.M., Siculella L., Caputi Jambrenghi A.M., Ragni M., Vonghia G., Gnoni G.V. 2001. Fatty acid chain elongation synthesis in eel (Anguilla anguilla) liver mitochondria. Comparative Biochemistry and Physiology Part B: Biochemistry and Molecular Biology 128 (1): 11-18. DOI: 10.1016/S1096-4959(00)00307-9

Goodman-Lowe G.D., Carpenter J.R., Atkinson S., Ako H. 1999. Nutrient fatty acid, amino acid and mineral analysis of natural prey of the Hawaiian monk seal, Monachus schauinslandi. Comparative Biochemistry and Physiology Part A: Molecular and Integrative Physiology 123 (2): 137-146. DOI: $10.1016 /$ S1095-6433(99)00038-0

Haro A., Castro-Santos T. 2000. Behavior and passage of silver-phase American eels, Anguilla rostrata (LeSueur) at a small hydroelectric facility. Dana 12: 33-42. 
Heffer-Lauc M., Mojsovic-Cuic A., Hrabac P., Viljetic B., Dikic D. 2010. The quest for the ganglioside functions what did we learn more from «evo-devo» or signaling of long-term maintenance? Biopolymers and Cell 26 (2): 105-114.

DOI: $10.7124 / \mathrm{bc} 00014 \mathrm{C}$

Hixson S.M., Sharma B., Kainz M.J., Wacker A., Arts M.T. 2015. Production, distribution, and abundance of long-chain omega-3 polyunsaturated fatty acids: A fundamental dichotomy between freshwater and terrestrial ecosystems. Environmental Reviews 23 (4): 414-424.

DOI: $10.1139 / \mathrm{er}-2015-0029$

Kabeya N., Yamamoto Y., Cummins S.F., Elizur A., Yazawa R., Takeuchi Y., Haga Y., Satoh S., Yoshizaki G. 2015. Polyunsaturated fatty acid metabolism in a marine teleost, Nibe croaker Nibea mitsukurii: Functional characterization of Fads2 desaturase and Elov15 and Elovl4 elongases. Comparative Biochemistry and Physiology Part B: Biochemistry and Molecular Biology 188: 37-45.

DOI: 10.1016/j.cbpb.2015.06.005

Leaver M.J., Bautista J.M., Björnsson B.T., Jönsson E., Krey G., Tocher D.R., Torstensen B.E. 2008. Towards fish lipid nutrigenomics: Current state and prospects for fin-fish aquaculture. Reviews in Fisheries Science 16 (Suppl. 1): 73-94. DOI: $10.1080 / 10641260802325278$

Li K., Østensen M.-A., Attramadal K., Winge P., Sparstad T., Bones A.M., Vadstein O., Kjørsvik E., Olsen Y. 2015. Gene regulation of lipid and phospholipid metabolism in Atlantic cod (Gadus morhua) larvae. Comparative Biochemistry and Physiology Part B: Biochemistry and Molecular Biology 190: 16-26.

DOI: 10.1016/j.cbpb.2015.08.006

Liang X., Zhao Y., Li Y., Gao J. 2016. Identification and structural characterization of two peroxisome proliferator activated receptors and their transcriptional changes at different developmental stages and after feeding with different fatty acids. Comparative Biochemistry and Physiology Part B: Biochemistry and Molecular Biology 193: 9-16.

DOI: $10.1016 /$ j.cbpb.2015.12.002

Lie Ø., Hemre G.-I., Lambertsen G. 1990. A comparison of the composition of cultured and wild caught European eel (Anguilla anguilla), particularly regarding lipids. Fiskeridirektoratets Skrifter, Serie Ernæring 3 (2): 3-11.

Lombardi V.R.M., Pereira J., Etcheverría I., Fernández-Novoa L., Seoane S., Cacabelos R. 2006. Improvement of immune function by means of Conger conger extract in an in vivo rat model of cold stress. Food and Agricultural Immunology 17 (2): 115-127. DOI: $10.1080 / 09540100600916569$

Matić-Skoko S., Ferri J., Tutman P., Skaramuca D., Đikić D., Lisičić D., Franić Z., Skaramuca B. 2012. The age growth and feeding habits of the European conger eel, Conger conger (L.) in the Adriatic Sea. Marine Biology Research 8 (10): 1012-1018.

DOI: $10.1080 / 17451000.2012 .706307$

Matić-Skoko S., Tutman P., Bojanić Varezić D., Skaramuca D., Đikić D., Lisičić D., Skaramuca B. 2014. Food preferences of the Mediterranean moray eel, Muraena helena (Pisces, Muraenidae), in the southern Adriatic Sea. Marine Biology Research 10 (8): 807-815. DOI: 10.1080/17451000.2013.863351

Matić-Skoko S., Tutman P., Petrić M., Skaramuca D., Đikić D., Lisičić D., Skaramuca B. 2011. Mediterranean moray eel Muraena helena (Pisces, Muraenidae): biological indices for life history. Aquatic Biology 13 (3): 275-284.

DOI: $10.3354 / \mathrm{ab} 00373$

Mazzeo I., Gallego V., Pérez L., Peñaranda D.S., Jover M., Asturiano J.F. 2010. Variations in fatty acids composition in different tissues of the European eel (Anguilla anguilla L.) males during induced sexual maturation. Journal of Applied Ichthyology 26 (5): 763-774.

DOI: $10.1111 / \mathrm{j} .1439-0426.2010 .01546 . x$

Monroig Ó., Li Y., Tocher D.R. 2011. Delta-8 desaturation activity varies among fatty acyl desaturases of teleost fish: High activity in delta- 6 desaturases of marine species. Comparative Biochemistry and Physiology Part B: Biochemistry and Molecular Biology 159 (4): 206-213.

DOI: $10.1016 /$ j.cbpb.2011.04.007

Mu H., Müllertz A. 2015. Marine lipids and the bioavailability of omega-3 fatty acids. Current Nutrition and Food Science 11 (3): 177-187.

DOI: $10.1016 /$ j.cbpb.2015.12.002

Murray D.S., Hager H., Tocher D.R., Kainz M.J. 2015. Docosahexaenoic acid in Arctic charr (Salvelinus alpinus): The importance of dietary supply and physiological response during the entire growth period. Comparative Biochemistry and Physiology Part B: Biochemistry and Molecular Biology 181: 7-14.

DOI: $10.1016 /$ j.cbpb.2014.11.003

Oku T., Sugawara A., Choudhury M., Komatsu M., Yamada S., Ando S. 2009. Lipid and fatty acid compositions differentiate between wild and cultured Japanese eel (Anguilla japonica). Food Chemistry 115 (2): 436-440.

DOI: 10.1016/j.foodchem.2008.12.032

Palmerini C.A., Mazzoni M., Giovinazzo G., Arienti G. 2009. Blood lipids in Antarctic and in temperatewater fish species. Journal of Membrane Biology 230 (3): 125-131.

DOI: $10.1007 / \mathrm{s} 00232-009-9192-2$

Peninal S., Elavarasi A., Kalaiselvam M. 2012. Fatty acid and amino acid composition of marine eels Congresox talabanoides and Thyrsoidea macrura from Parangipettai coastal waters. International Journal of Pharmacological and Biological Archives 3 (4): 952-957. 
Rupia J.E., Shen J., Wu J., Chen W., Liu L., Dierckens K., Sorgeloos P., Lu W. 2014. Effect of hormone injection frequency on the lipid content and fatty acid compositions in gonad, muscle and liver of Anguilla japonica during artificial maturation. Aquaculture International 22: 1105-1120.

DOI: $10.1007 /$ s10499-013-9731-9

Sallami B., Ben Salem M., Reynaud C., Capapé C. 2014. Diet of Mediterranean moray, Muraena helena (Actinopterygii, Anguilliformes, Muraenidae), from the north-eastern Tunisian coast (central Mediterranean). Acta Ichthyologica et Piscatoria 44 (4): 273-283.

DOI: 10.3750/AIP2014.44.4.01

Sallami B., Ben Salem M., Reynaud C., Capapé C. 2015. Diet of European conger eel Conger conger (Osteichthyes, Congridae) from the northeastern coast of Tunisia (central Mediterranean). Cahiers de Biologie Marine 56 (3): 253-262.

Shahidi F., Finley J.W. 2001. Omega-3 fatty acids: chemistry, nutrition, and health effects. American Chemical Society, Washington DC, USA.

Shahkar E., Yun H., Lee S., Kim D.-J., Kim S.-K., Lee B.I., Bai S.C. 2016. Evaluation of the optimum dietary arachidonic acid level and its essentiality based on growth and non-specific immune responses in Japanese eel, Anguilla japonica. Aquaculture 452: 209-216. DOI: 10.1016/j.aquaculture.2015.10.034

Støttrup J.G., Jacobsen C., Tomkiewicz J., Jarlbæk H. 2013. Modification of essential fatty acid composition in broodstock of cultured European eel Anguilla anguilla L. Aquaculture Nutrition 19 (2): 172-185.

DOI: $10.1111 / j .1365-2095.2012 .00967 . x$

Teparić R., Landeka I., Tomić J., Đikić D. 2012. Influence of dietary treatment on lipid metabolism in metabolic syndrome. Croatian Journal of Food Technology, Biotechnology and Nutrition 7 (1-2): 69-77.

Tillander V., Bjørndal B., Burri L., Bohov P., Skorve J., Berge R.K., Alexson S.E. 2014. Fish oil and krill oil supplementations differentially regulate lipid catabolic and synthetic pathways in mice. Nutrition and Metabolism: eCollection 2014.

DOI: $10.1186 / 1743-7075-11-20$
Tocher D.R. 2003. Metabolism and functions of lipids and fatty acids in teleost fish. Reviews in Fisheries Science 11 (2): 107-184.

DOI: $10.1080 / 713610925$

van Ginneken V., Durif C., Balm S.P., Boot R., Verstegen M.W.A., Antonissen E., van Den Thillart G. 2007. Silvering of European eel (Anguilla anguilla L.): Seasonal changes of morphological and metabolic parameters. Animal Biology 57 (1): 63-77. DOI: $10.1163 / 157075607780002014$

Varljen J., Šulić S., Brmalj J., Batičić L., Obersnel V., Kapović M. 2003. Lipid classes and fatty acid composition of Diplodus vulgaris and Conger conger originating from the Adriatic Sea. Food Technology and Biotechnology 41 (2): 149-156.

Wang S., Monroig O., Tang G., Zhang L., You C. Tocher D.R., Li Y. 2014 Investigating long-chain polyunsaturated fatty acid biosynthesis in teleost fish: Functional characterization of fatty acyl desaturase (Fads2) and Elovl5 elongase in the catadromous species, Japanese eel Anguilla japonica. Aquaculture 434: $57-65$.

DOI: $10.1016 /$ j.aquaculture.2014.07.016

Weylandt K.H., Serini S., Chen Y.Q., Su H.M., Lim K., Cittadini A., Calviello G. 2015. Omega-3 polyunsaturated fatty acids, the way forward in times of mixed evidence. BioMed Research International 2015: article ID 143109. DOI: $10.1155 / 2015 / 143109$

Xue X., Feng C.Y., Hixson S.M., Johnstone K., Anderson D.M., Parrish C.C., Rise M.L. 2014. Characterization of the fatty acyl elongase (elovl) gene family and hepatic elovl and delta- 6 fatty acyl desaturase transcript expression and fatty acid responses to diets containing camelina oil in Atlantic cod (Gadus morhua). Comparative Biochemistry and Physiology Part B: Biochemistry and Molecular Biology 175 (1): 9-22.

DOI: $10.1016 /$ j.cbpb.2014.06.005

Received: 29 July 2016 Accepted: 10 December 2016 Published electronically: 31 March 2017 